<総 説 $>$

(受理 : 平成 23 年 2 月 9 日)

\title{
セルロースナノファイバー補強透明フィルムの製造と特性 Production of Cellulose Nanofiber Reinforced Optically Transparent Film and Its Properties
}

\section{1.はじめに}

20 世紀を支えた「炭酸ガス排出型マテリアル」から， 「炭酸ガス吸収固定型マテリアル」へのパラダイム転換が 叫ばれる中, 太陽の光により水と炭酸ガスから持続的に生 産される植物バイオマスのマテリアル利用に関心が集まっ ている。

植物の基本構成単位が細胞であることは良く知られてい るが, 細胞がナノファイバーで構築されていることについ てはほとんど知られていない。驚くべきことにこのナノ ファイバーは細いだけでなく，セルロースの伸びきり鎖微 結晶で出来ているため, 鋼鉄の $1 / 5$ の軽さで, その 5 倍 以上の強度を有している。また, 線熱膨張係数がガラスの $1 / 50$ 以下と極めて小さい。さらに, 弾性率がー $200^{\circ} \mathrm{Cか}$ ら+200ㄷの範囲でほぼ一定である。

このような高性能でかつ無尽蔵といっても良いナノファ イバーでありながら，その工業的利用はナノファイバーレ ベルまでの解䄉コスト，ナノファイバー故の取り扱いの難 しさなどから、これまでほとんどなされてこなかった。し かし，近年，新規の低環境負荷グリーンナノ材料として， 北欧や北米で急速に研究が活発化している ${ }^{1 \sim 5)}$ 。われわれ は，このような世界の動きに先駆けて 10 年ほど前からセ ルロースナノ織維の製造や樹脂との複合化に取り組んでき た。その中で，セルロースナノファイバーの特徽を活かし たさまざまなナノ材料を開発している。本稿ではそのうち 透明補強用ナノ繊維としてのセルロースナノファイバー利 用について概説する。

\footnotetext{
* 京都大学 生存圈研究所 京都府宇治市五ヶ庄 干 611-0011

Research Institute for Sustainable Humanosphere, Kyoto University Gokasho, Uji, Kyoto 611-0011, Japan
}

\section{2. セルロースナノファイバーの構造と物性}

セルロースナノファイパーは，もっとも基本となる単位 であるセルロースミクロフィブリルから（図 1), それが 4 本程度のゆるやかな束となって細胞壁中での基本単位とし て存在するセルロースミクロフィブリル束（図 2), その ようなミクロフィブリル束がさらに数 10 一数百 $\mathrm{nm}$ の束

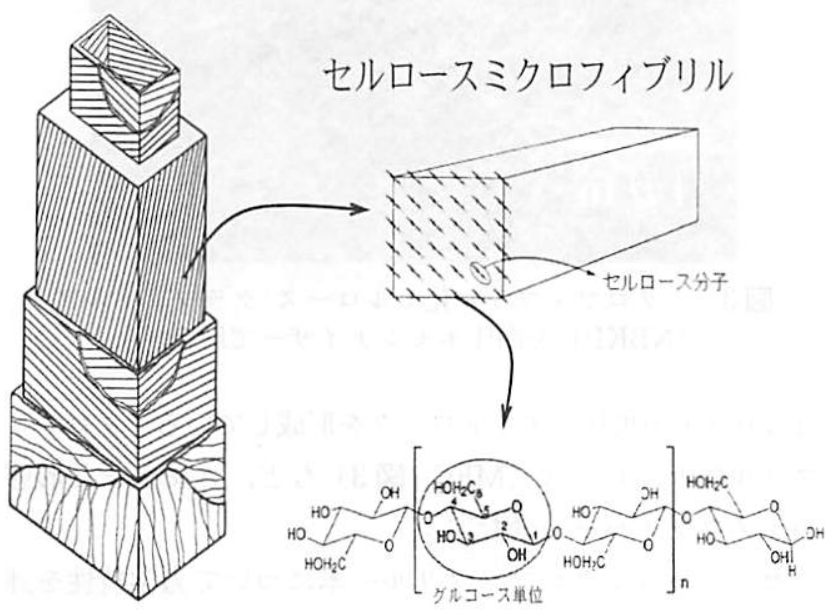

細胞壁モデル セルロース分子鎖

図 1 木材の細胞構造とセルロースナノファイバー

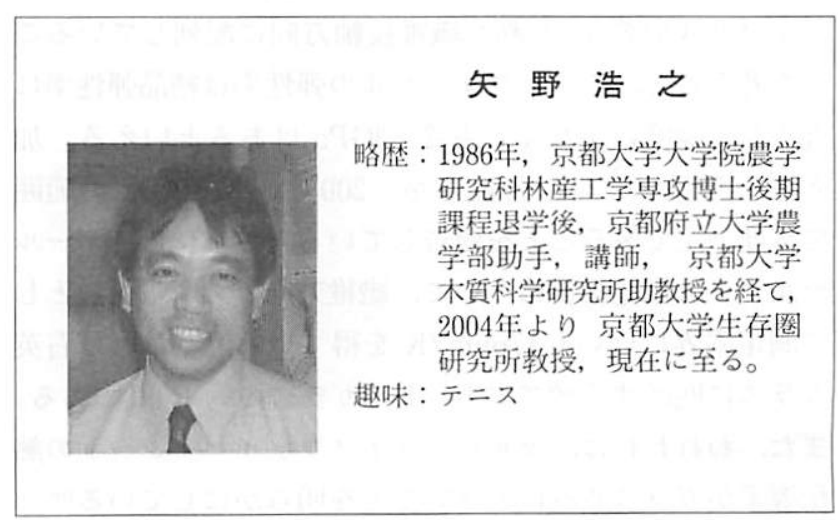




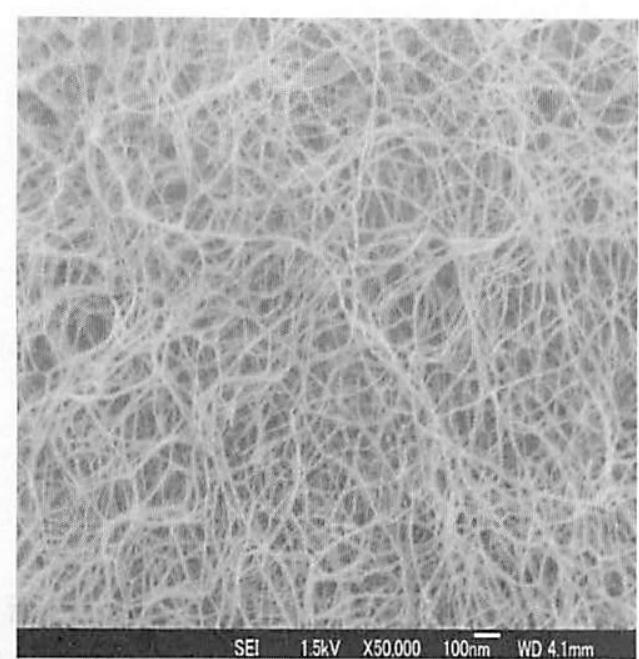

図 2 木材細胞壁中のセルロースナノファイバー。困中のバー は $100 \mathrm{~nm}_{0}$ 。(京都大学, 粟野博士提供)

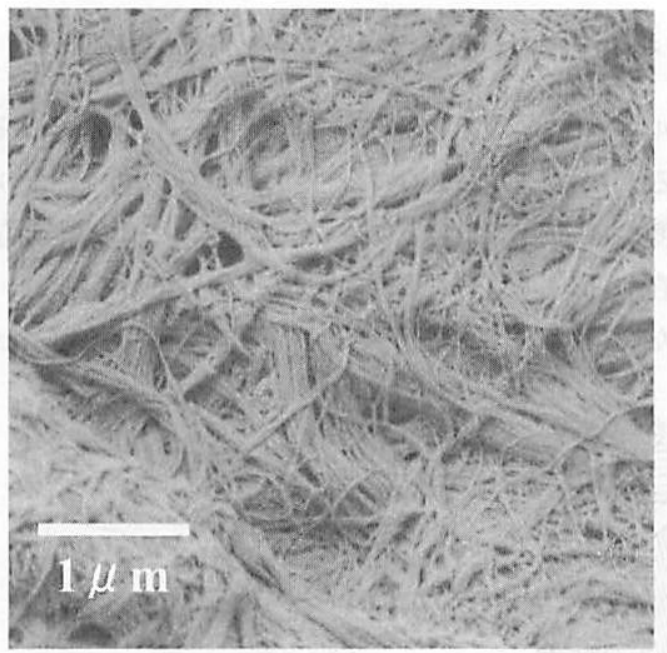

図 3 ミクロフィブリル化セルロース クラフトパルプ （NBKP）を高圧ホモジナイザーで解㵶。

となりクモの巣状のネットワークを形成しているミクロフィ ブリル化セルロース（MFC, 図 3）など, さまざまな形態 のナノファイバーを含む。

セルロースミクロフィブリル一本について力学特性を評 価した例はないが, Pageらは，その集合体であるクラフ トパルプ織維について引張武験で約 $100 \mathrm{GPa}$ の弾性率之 $1.7 \mathrm{GPa}$ の強度を得ている ${ }^{6)}$ 。パルプ繊維においてミクロ フィブリルの約 7-8 割が繊維長軸方向に配列しているこ とを考えると, ミクロフィブリルの弾性率は結晶弾性率に 近く ${ }^{7)}$, 強度は少なくとも $2-3 \mathrm{GPa}$ はあるといえる。加 えて, 西野ら ${ }^{8)}$ は, 弾性率が $-200^{\circ} \mathrm{C} ら+200^{\circ} \mathrm{C}$ の範囲 でほぼ一定であることを報告している。さらには，オール セルロース繊維材料について, 繊維方向の熱膨張係数とし て測定限界に近い $0.17 \mathrm{ppm} / \mathrm{K}$ を得ている ${ }^{9)}$ 。これは石英 ガラスに匹敵する值であり，E一ガラスの約 $1 / 50$ である。 また，われわれは，セルロースナノファイバーシートの熱 伝導率がガラス並みに大きいことを明らかにしている ${ }^{10)} 。$

\section{3. セルロースナノファイバーおよびウィスカーの 製造}

木材パルプなど植物系織維材料からのセルロースナノファ イバー製造について, 種々の方法が開発されている。数\% 濃度のパルプスラリーについて行う低濃度での解䋐技術と しては, 高圧ホモジナイザー法 ${ }^{11)}$, マイクロフリュイダ イザー法 ${ }^{12 \sim 14)}$, グラインダー磨砕法 ${ }^{15 \sim 17)}$, 凍結粉砕法 ${ }^{18)}$, 超音波解織法 ${ }^{19)}$, 高速摚拌法（上谷）がある ${ }^{20)}$ 。低濃度 での解織は均一なナノファイバーを得やすいが, 解織効率 やその後の脱水プロセスに起因してコスト高である。固形 分が数 $10 \%$ 程度のパルプ・水混合物を出発点とした解䄉 技術として二軸混練機などを用いた強せん断混練法 ${ }^{21)} や$ ボールミル粉砕法 ${ }^{22)}$ などがある。ポリマー存在下での混 練や粉砕によるナノファイバー化は, ポリマー中への均一 フィラー分散を同時に行える可能性があり, 複合材料への ナノファイバー利用において有利である。

斉藤・磯具らは, TEMPO (2,2,6,6-tetramethyl-1piperidinyloxy radical）を触媒に用い, 水系で非晶領域 にある 6 位のセルロース水酸基を選択的にカルボキシル化 すると, ナノファイバー相互の反発性が高まり, ナノファ イバー化が促進されることを明らかにしている ${ }^{23)}$ 。ミキ サー等の極めてゆるやかな機械処理によってもミクロフィ ブリルのレベルまで均一にナノファイバー化でき, 乾燥後, ナノファイバーを水中に再分散できる。同様の効果は, 七 ルロースナノファイバー表面にある水酸基をカルボキシル メチル化処理してあ得られる ${ }^{24,25)}$ 。ナノファイバー化の 促進については酵素を用いた検討もなされている ${ }^{13,14,26,27)}$ 。 植物パルプや動物性セルロースナノファイバー（チュニ ケート) を強酸で処理し, ホモジナイザー等で切断すると 針状結晶物質, ナノウィスカーが得られる。セルロースナ ノウィスカーの基本的な製造技術は 1955 年に見いだされ， その後, 工業化され, 製薬, 食品, 飲料, 化粰品等, さま ざまな分野で添加剤として利用されている ${ }^{28)}$ 。

セルロースナノファイバーは全ての植物資源が原料とな り得る。これまで木材パルプ以外に, 竹, 稲ワラ, バガス (サトウキビの絞りカス), ジャガイモやキャッサバのデン プン絞りカス, 砂糖ダイコン（シュガービート）の絞りカ ス（図 4), あるいは烓酎力スといった農産廃车物や産業 廃衰物から屯幅 20-50nm 程度の均一ナノファイバーが得 られている29,30)。

セルロースナノファイバーには，酢酸菌などのバクテリ アが産出するものもある。ナタデココといった方が馴染み があるかむしれない。身近なデザート食品である。植物原 料は細胞壁からマトリックス成分を取り除き, 機械的解繊 によりナノファイバーを取り出す必要があるが, バクテリ アセルロースではバクテリアが培養液中でナノファイバー 


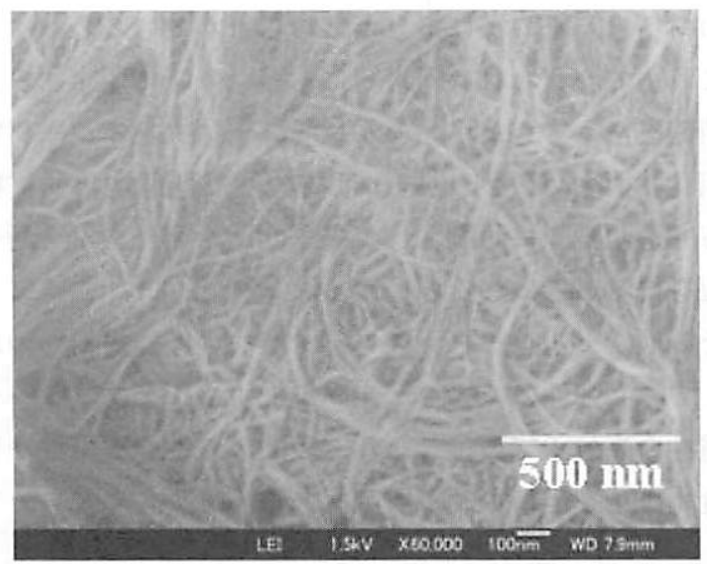

図4 砂糖ダイコン（シュガーピート）パルプから抽出した ナノファイバー

を紡ぎながら移動し，かつ分裂するため，幅 50-100nm のセルロースナノファイバーが，凝集することなく溶液中 に均一に分散したネットワーク構造体が容易に得られる。 このため, 高弾性のゲル状シートとして, 人工血管や傷口 治療用シートなど, 医療関係への応用が多く研究されてい る331)。バクテリアセルロースの乾燥シートが軽量・高弾 性のスピーカ振動板として用いられている例むある32)。

\section{4. ナノファイバー強化透明材料}

ナノファイバーには透明樹脂の補強用䋐維としての期待 がある。光波長の $1 / 10$ 以下の大きさのコンポーネント （要素）は光の散乱を生じない,という物理的原理に基つ くものである。すなわち，可視光波長 $(400-800 \mathrm{~nm})$ の 1/10 以下の大きさの物体は, 材料に混合されても可視光 の散乱を生じない。このため, 耐熱性あるいは強度特性に 優れたナノ材料を透明樹脂中に均一分散することで，樹脂 の透明性を保ちながら耐熱性や強度特性を改善できる。 われわれは，最初に，バクテリア (Acetobacter xylinum) が産出するセルロースミクロフィブリル束が, 幅 $50 \mathrm{~nm}$ と 可視光波長に対して十分細く均一であることに着目し（図 5)，バクテリアセルロースを用いた透明樹脂補強について 検討した ${ }^{33 \sim 38)}$ 。

バクテリアセルロースのペリクル（ナタデココの状態） を加熱しながらプレス脱水すると，フィルム状の白色シー トが得られる。このシートに屈折率がセルロースに近い透 明アクリル樹脂やエポキシ樹脂を注入するとシートは透明 になる。織維含有率が約 $60 \%$ むあるにも関わらず，光透 過率は透明樹脂に比べ $10 \%$ 程度しか低下しない。高強度, 低熱膨張の織維で補強されているので，この透明ナノ繊維 強化材料は, 鋼鉄に近い強度（引張強度 : $320 \mathrm{MPa）とと}$ もに，ガラスやシリコン結晶に匹敵する低線熱膨張（3$7 \mathrm{ppm} / \mathrm{K})$ を示す。しかも，フレキシブルで大きく曲げら れる ${ }^{33)}$ (図 6)。

さらに，セルロースナノファイバー補強によるサイズ効

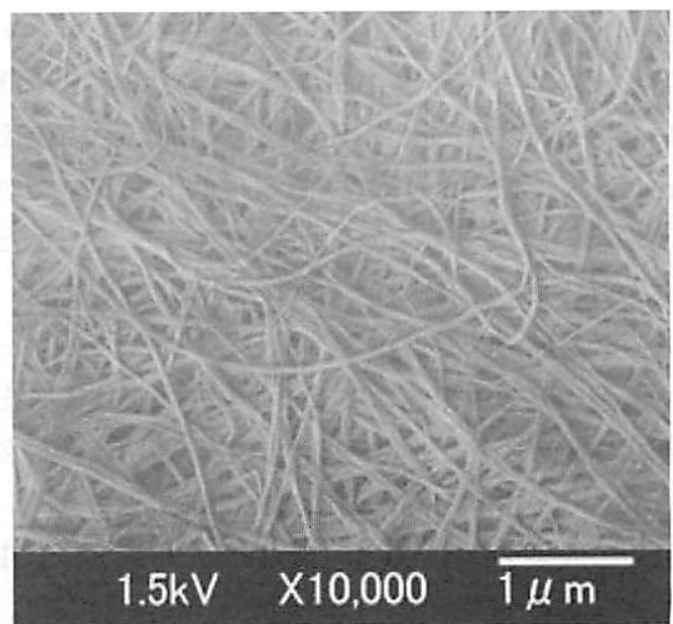

図 5 バクテリアセルロース $(\mathrm{BC})$ シート

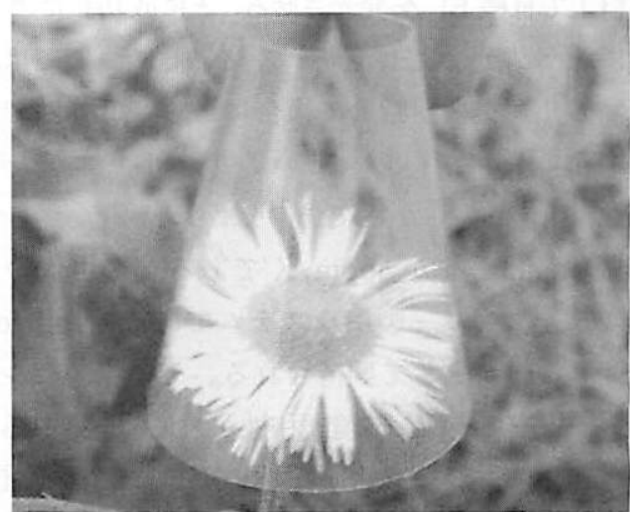

図 6 セルロースナノファイバー補強透明材料

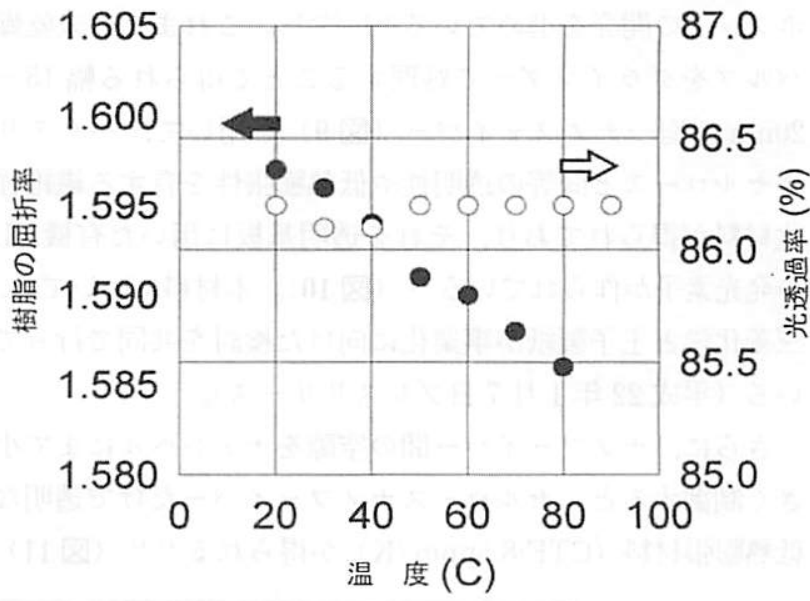

図 $7 \mathrm{BC}$ 補強透明材料における光透過率の温度依存性

果で透明性が保たれるため, 幅広い屈折率を有する樹脂に 対して透明補強が可能である。例えば，繊維を $60 \%$ 含有 した状態で，樹脂の屈折率を 1.53 1.64 まで変化させても， 直線透過率の低減はわずか $2 \%$ 以内に収まる ${ }^{7)}$ 。さらに, 図 7 に示すように，樹脂（ポリマー）は温度变化に伴い屈 折率が変化するため，屈折率のマッチングにより透明性を 得る場合は温度変化に伴って透明性が損なわれてしまうが, バクテリアセルロースで補強した透明材料は, $20^{\circ} \mathrm{C}$ か $80^{\circ} \mathrm{C}$ まで温度が変化しても透明性は全く変化しない34。 
バクテリアセルロースによる透明補強では，ネットワー ク構造とセルロースナノファイバーの高弾性率・低熱膨 張性に起因して，わずか $7 \%$ 緎維添加で熱膨張係数が $80 \mathrm{ppm} / \mathrm{K}$ から $40 \mathrm{ppm} / \mathrm{K}$ まで急激に低下する。それによ る透明樹脂の直線透過率低下は $2 \%$ である ${ }^{35)}$ 。また， 七 ルロースナノファイバー補強材料の実用においては, セル ロースの吸湿性が問題となることが多いが，セルロース表 面の水酸基のみを選択的にアセチル基に置換することで, 低熱膨張性や透明性を損なうことなく，透明複合材料の吸 湿性をアクリル樹脂と同程度にまで抑制できる ${ }^{36,37) 。 ~}$

これらの成果を踏まえ，われわれは，有機 EL (OLED) ディスプレイの透明基板への応用について検討した。数々 の処理プロセスの改良を経て, バクテリアセルロース補強 透明材料上で有機 EL を発光させることに成功した ${ }^{38)}$ (図 8)

さらに，バクテリアセルロースシートについては，低弾 性率のマトリックス樹脂との複合により, 低弾性でかつ低 熱膨張の透明材料が得られている ${ }^{39)}$ 。ポリエチレン樹脂 (HDPE) 相当の柔らかさでありながら，驚くべきことに 線熱膨張係数はわずか $4 \mathrm{ppm} / \mathrm{K}$ である。次世代のフラッ トパネルディスプレー製造システムである "Roll to Roll” 用の透明基板材料として期待される。その際, セルロース ナノファイバーの優れた環境調和性が大量製造されるフラッ トパネルディスプレーや太陽電池の廃棄に関して重要にな ると思われる。

最近では，資源的に豊富な植物織維からの透明ナノコン

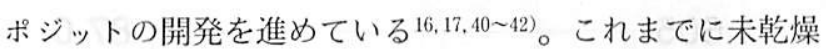
パルプをグラインダーで処理することで得られる幅 $15-$ $20 \mathrm{~nm}$ の均一ナノファイバー（図 9）を用いて, バクテリ アセルロースと同等の透明性や低熱膨張性を有する㵶維強 化材料が得られており，それを透明基板に用いた有機 EL の発光素子が作られている ${ }^{42}$ （図 10）。本材料については, 三菱化学と王子製紙が事業化に向けた検討を共同で行って いる(平成 22 年 1 月 7 日プレスリリース)。

さらに,ナノファイバー間の空隙をナノレベルにまで小 さく制御すると，セルロースナノファイバーだけで透明な

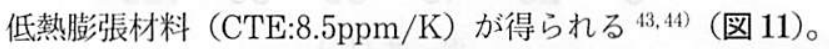

この材料は，紙の様に折りたたむことができる。

これまでわれわれは何世紀にもわたり紙に印字すること で情報を伝えてきたが，セルロースナノファイバー材料が 実用化されれば，21 世紀には持続型で低環境負荷材料で ある “透明紙”に印刷された電子回路や発光素子を通じて 情報を得ることになるといえる。

その他, セルロースナノファイバーの機能材料への応用 として, 高弾性のエアロゲルへの加工やナノファイバーを 導電性の高分子で被覆したり, 表面に磁性や導電性を有し た金属粒子を担持させる研究がある ${ }^{2,45 \sim 47) 。 セ ル ロ ー ス ナ ~}$

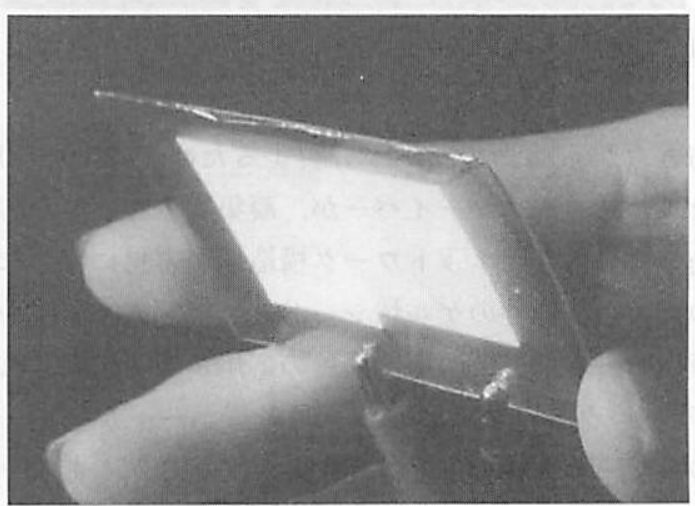

図 8 セルロースナノファイバー補強透明材料を透明基板 に用いた EL 発光素子

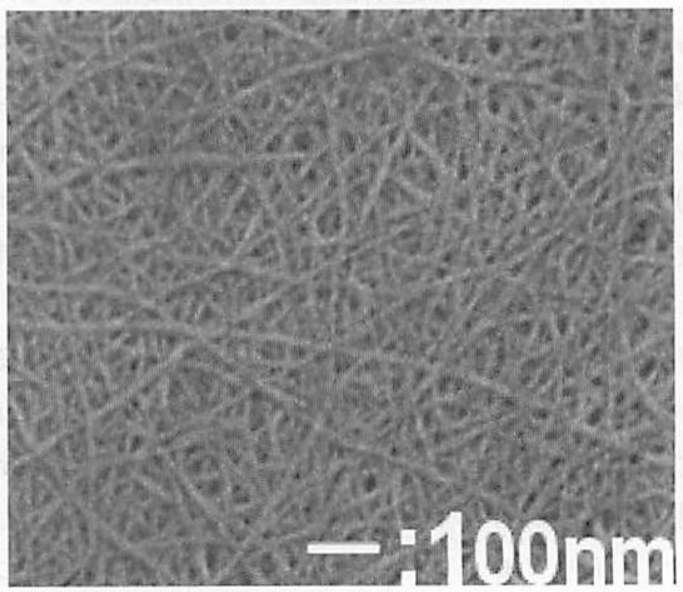

図 9 グラインダー処理で木材から取り出した幅 15-20nm のセルロースナノファイバー束

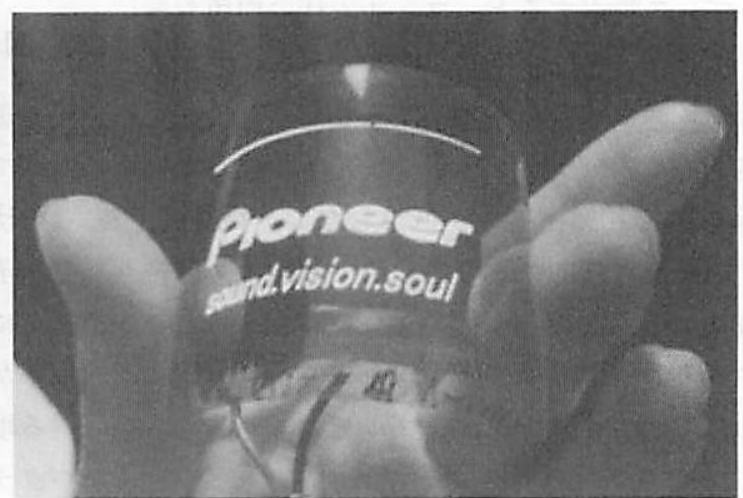

図 10 セルロースナノファイバー補強透明材料（左）とそれを基板に用いた有機 EL 発光素子（右） 


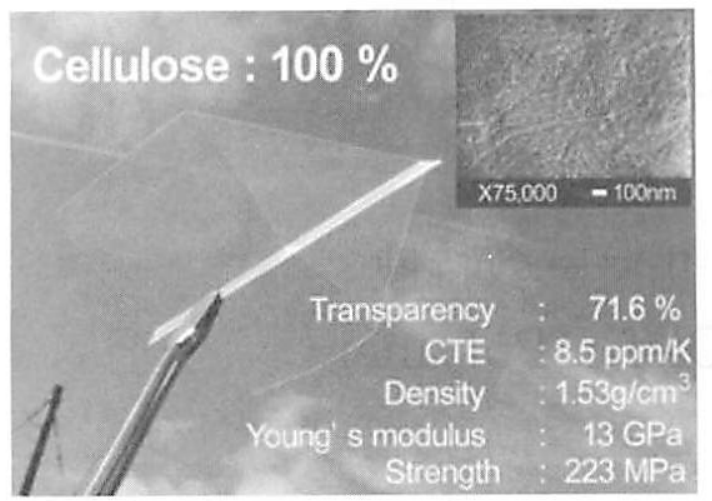

図 11 100\%セルロースナノファイバーで出来た透明材料

ノファイバーの特徴の一つは化学的に表面修飾しやすいこ とである。今後は, この化学修飾性を活かし，高弾性で大 きな比表面積を有するセルロースナノファイバーをスキャ フォールドやテンプレートとして用いる研究も盛んになる と考えられる。

\section{5.おわりに}

セルロースナノ材料は, (1)高強度・低熱膨張, (2)リニュー アブル (持続性), (3) $\mathrm{CO}_{2}$ 排出抑制（カーボンニュートラ ル), (4)安全・安心（生体適合性), (5)マテリアル・サーマ ルリサイクル可能，(6)低環境負荷（生分解性付与)，(7)農 産廃棄物・産業廃棄物の再資源化，など，多くの優れた特 性を有している。しかも，エレクトロンスピニングによる ナノファイバーに比べ，安価で大量に製造できる。透明材 料や構造材料への用途以外に，紡糸して極細・高強度繊維 材料を製造したり，フィルターや滤過材に用いることも可 能であろう。あるいは, ノンカロリーの食物織維（ダイエッ タリーファイバー), 安心安全な食べられるナノファイバー としての利用も考えられる。

この様に，セルロースナノファイバーは，我が国におけ る川上から川下までの幅広い産業, すなおち, 製紙産業, 化学産業, 繊維産業, 自動車産業, IT 産業, 食品産業, 医療産業，成型加工業等に関わる材料であり，即効性があ るため, 低炭素社会の急速な実現とともに, 今後, 短期間 での大きな経済効果が期待できるといえる。

\section{引用 文 献}

1) S. J. Eichhorn, et al., J. Mater. Sci., 45, 1 (2010).

2) L. A. Berglund, T. Peijs, MRS Bulletin, 35, 201 (2010).

3) P. Gatenholm, D. Klemm, MRS Bulletin, 35, 208 (2010).

4) A. N. Nakagaito, M. Nogi, H. Yano, MRS Bulletin, 35, 214 (2010).

5) I. Siró, D. Plackett, Cellulose, 17, 459 (2010)

6) D. H. Page, F. EL-Hosseiny, Journal of Pulp and Paper Science, 9, 99 (1983).

7) I. Sakurada, Y. Nukushina, T. Ito, Journal of Polymer Science, 57, 651 (1962).

8) T. Nishino, M. Kotera, M. Kimoto, Proc.2nd Intn'l Cellulose Conf. 2007, 125, October, 2007.
9) T. Nishino, I. Matsuda, K. Hirao, Macromolecules, 37 , $7683(2004)$.

10) Y.Shimazaki, Y.Miyazaki, Y.Takezawa, M.Nogi, K.Abe, S. Ifuku, H. Yano, Biomacromolecules, 8, 2976 (2007).

11) A. F. Turbak, F. W. Snyder, K. R. Sandberg, Journal of Applied Polymer Science, Applied Polymer Symposium, 37, 815 (1983).

12) T. Zimmermann, E. Pohler, T. Geiger, Advanced Engineering Materials, 6, 754 (2004).

13) M. Paakko, et al., Biomacromolecules, 8, 1934 (2007).

14) M. Henriksson, et al., Biomacromolecules, 9, 1579 (2008).

15) T. Taniguchi, K. Okamura, Polymer International, 47, 291 (1998).

16) S. Iwamoto, H. Yano, A.N. Nakagaito, M. Nogi, Applied Physics A, 81, 1109 (2005).

17) K. Abe, S. Iwamoto, H. Yano, Biomacromolecules, 8, 3276 (2007).

18) A.Bhatnagar, M.M. Sain, Journal of Reinforced Plastics and Composites, 24, 1259 (2005).

19) H. - P. Zhao, X.-Q., Feng. H. Gao, Applied Physics Letters, 90, 073112 (2007).

20) K. Uetani, H. Yano, Biomacromolecules, in press.

21）矢野浩之, 矢野一憲, 茂木優子, 特許 4013870 .

22）碚貝明, セルロースの科学（朝倉書店), 159 (2003)

23) T. Saito, Y. Nishiyama, J. Putaux, M. Vignon, A. Isogai, Biomacromolecules, 7, 1687 (2006).

24) Ch. Eyholzer, et al., Cellulose, 17, 19(2010).

25) Ch. Eyholzer, et al., Cellulose, 17, 793 (2010).

26) S. Janardhnan, M. M. Sain, Bioresources, 1, 176 (2006).

27) M.Henriksson, et al., European Polymer Journal, 43, 3434 (2007)

28）飯嶋秀樹，セルロース学会編，七ルロースの事典 (朝倉書店), 522 (2003)

29) K. Abe, H. Yano, Cellulose, 16, 1017 (2009).

30 ) 矢野浩之, H19 年度 NEDO 国際共同研究先導調查報告書.

31) D.Klemm, D.Schumann, F.Kramer, N.Hesler, M.Hornung, H. - P. Schmauder, S. Marsch, Advances in Polymer Science, 205, 49 (2006).

32) S. Yamanaka, K. Watanabe, N. Kitamura, M. Iguchi, S. Mitsuhashi, Y. Nishi, M. Uryu, Journal of Materials Science, 24, 3141 (1989).

33) H. Yano, J. Sugiyama, A. N. Nakagaito, M. Nogi, T. Matsuura, M. Hikita, K. Handa, Advanced Materials, 17, 153 (2005)

34) M. Nogi, K. Handa, A. N. Nakagaito, H. Yano, Applied Physics Letters, 87, 243110 (2005).

35) M. Nogi, S. Ifuku, K. Abe, K. Handa, A. N. Nakagaito, H. Yano, Applied Physics Letters, 88, 133124 (2006)

36) M. Nogi, K. Abe, K. Handa, F. Nakatsubo, S. Ifuku, H. Yano, Applied Physics Letters, 89, 233123 (2006).

37) S. Ifuku, M. Nogi, K. Abe, K. Handa, F. Nakatsubo, H. Yano, Biomacromolecules, 8, 1973 (2007).

38）矢野浩之, 能木雅也, 半田敬信, 久保田広文,バイオサイエン スとインダストリー, 63(11), 28 (2005)

39) M. Nogi, H. Yano, Advanced materials, 20, 1849 (2008).

40) S. Iwamoto, A. N. Nakagaito, H. Yano, Applied Physics A, 89, 461 (2007).

41) S. Iwamoto, K. Abe, H. Yano, Biomacromolecules, 9, 1022 (2008).

42) Y. Okahisa, A. Yoshida, S. Miyaguch, H. Yano, Composites Science and Technology, 69(11-12), 1958 (2009).

43) M.Nogi, S.Iwamoto, A.N.Nakagaito, H. Yano, Advanced Materials, 21, 1595 (2009).

44) M. Nogi, H. Yano, Applied Physics Letters, 94, 231117 (2009).

45) G. Nyström, et al., J. Phys. Chem. B, 114, 4178 (2010).

46) S. Ifuku, et al., Biomacromolecules, 10, 2714 (2009).

47) R.T.Olsson, et al., Nature Nanotechnology, 5, 584 (2010). 